\title{
Nota Editorial
}

Aspiração antiga, a Revista do Departamento de Música da Escola de Comunicaçōes e Artes da Universidade de São Paulo atende à imperiosa necessidade do abrigar sob a égide da Universidade, em publicação específica, o conhecimento musical multidirecionado.

Da idéia inicial à configuração do modelo deste primeiro número foram vários os caminhos percorridos. O próprio significado da palavra Universidade ratificou critérios nos quais acreditamos.

A Revista Música terá compromisso único com a qualidade. Os textos recebidos serão analisados, a fim de possłvel publicação, pelo Conselho Editorial formado por músicos e pensadores sobre música da maior competência. A Revista estará atenta a textos internacionais que somados à produção nacional propiciará ao "corpus" da publicação um equilíbrio que julgamos se fazer necessário. A divulgação única de artigos, ensaios e estudos escritos por nossos especialistas poderia resultar em enclausuramento ou chauvinismo. Essa abertura, se, de um lado, propiciará a ventilação da Revista alêm de nossas fronteiras, por outro lado, suscitará reflexōes, comparaçōes, estímulo enfim.

Há de se considerar que o Departamento de Música mantém em seu corpo docente profissionais em música com amplo trânsito nos centros mais avançados da Europa e da América como um todo. Compositores, musicólogos, intérpretes participam anualmente de eventos fora do Brasil, o que acelera o intercâmbio no campo das idéias. Os contatos mantidos resultam em textos de alguns dos mais destacados pensadores musicais da atualidade, o que nos ajudará a estabelecer parâmetros, repensar o já pensado, estimular a sempre meta, qualidade, e sob outro prisma: comunicaçāo com os centros de estudos musicológicos mais avançados, o que traria como conseqüência a difusāo do pensamento musical realizado no Brasil.

François Lesure fala-nos de um aspecto que deve ser prioritário, ou seja, o debruçamento sobre a abrangência musical brasileira, preferencialmente a "(...)trabalhar uma vez mais as origens da forma Sonata". Interessa sim à nova revista a pormenorização de todas as manifestaçöes musicais em termos de Brasil, buscando-se as origens, explicando-se os caminhos, lançando-se as hipóteses de um amanhã.

Neste primeiro número não constam levantamentos nacionais sobre: discografia, publicações de livros e artigos, ensaios ou estudos especializados, assim como a nomeação de teses acadêmicas. Esperamos num segundo número divulgar essa produção relativa a 1989 de forma sistemática. O Departamento de Música da ECA USP chama a si a responsabilidade desse empreendimento que deverá, em prinć́pio, ter periodicidade semestral. Nossos agradecimentos ao Diretor da Escola de Comunicações e Artes da Universidade de Sāo Paulo, Professor Doutor Jose Marques de Melo, que se mostrou sensível à importância da publicação.

José Eduardo Martins

Prof. do Depto. de Música da ECA 